\title{
PARTISIPASI PEREMPUAN DALAM PEMBANGUNAN INFRASTRUKTUR JALAN PERTANIAN DI DESA WATULANEY TIMU KECAMATAN LEMBEAN TIMUR KABUPATEN MINAHASA
}

\author{
Ribka Mangimbulur \\ Melsje Yellie Memah \\ Elsje Pauline Manginsela
}

\begin{tabular}{ll}
\hline Naskah diterima melalui email dari Jurnal Ilmiah agrisosioekonomi@unsrat.ac.id & : Jumat, 19 April 2019 \\
Disetujui diterbitkan & : Rabu, 24 April 2019 \\
\hline
\end{tabular}

\begin{abstract}
This study aims to determine how much women's participation in the construction of agricultural road infrastructure. This research was conducted in Watulaney Village, East Lembean, Minahasa Regency and lasted for 3 months, from October to December 2018. Methods of data collection in this study used primary data collected through interviews based on a list of questions, using Likert Scale, that had been prepared previously. Secondary data obtained from the Office of the Village Watulaney Timu, local book stores, and internet throught google scholar to get article from journals and thesis from others university that related to this research topic. Data analysis using qualitative and quantitative descriptive analysis, where this method describes each data taken from women's participation and then presented in table form. For the measurement of women's participation using a Likert Scale. The research results showed that the level of women's participation in agricultural road infrastructure development programs was classified as very active in providing participation in the form of thoughts, energy, skills and assets and objects at the planning, implementation and evaluation stages. With a total score of 426 or $71 \%$, it can be said to be classified as very active. . $^{*}$ m $^{*}$
\end{abstract}

Keywords: women's participation, infrastructure development and level of participation

\begin{abstract}
ABSTRAK
Penelitian ini bertujuan untuk mengetahui seberapa besar partisipasi perempuan dalam pembangunan infrastruktur jalan pertanian. Penelitian ini dilakukan di Desa Watulaney Kecamatan Lembean Timur Kabupaten Minahasa dan berlangsung selama 3 bulan, dari bulan Oktober sampai Desember 2018. Metode pengumpulan data dalam penelitian ini menggunakan data primer yang dikumpulkan melalui wawancara berdasarkan daftar pertanyaan, yang menggunakan Skala Likert, yang sudah disiapkan sebelumnya. Data sekunder yang di peroleh dari Kantor Desa Watulaney Timu, toko buku lokal, internet melalui google cendekia untuk mendapatkan artikel dari berbagai jurnal ilmiah dan skripsi dari perguruan tinggi lain yang berkaitan dengan topik penelitian tentang Partisipasi Perempuan dalam Pembangunan Infrastruktur Jalan Pertanian. Analisis data yang menggunakan analisis deskriptif kualitatif dan kuantitatif. Hasil penelitian menunjukkan bahwa tingkat partisipasi perempuan dalam program pembangunan infrastruktur jalan pertanian tergolong sangat aktif dalam memberikan partisipasi berupa pikiran, tenaga, keterampilan serta harta dan benda pada tahap perencanaan, pelaksanaan dan evaluasi. Dengan jumlah total skor 426 atau $71 \%$ sehingga dapat dikatakan tergolong sangat aktif."epm"
\end{abstract}

Kata Kunci : partisipasi perempuan, pembangunan infrastruktur dan tingkat partisipasi

\section{PENDAHULUAN}

Latar Belakang

Keberhasilan pembangunan suatu daerah dapat dilihat dari cara pemerintah membangun wilayah atau daerah tersebut, dengan tujuan untuk mensejahterakan masyarakat. Menurut Siagian (2008) pembangunan merupakan suatu rangkaian usaha untuk mewujudkan pertumbuhan dan perubahan secara terencana serta sadar, yang ditempuh oleh suatu negara menuju modernisasi dalam rangka pembinaan bangsa. Indonesia merupakan salah satu negara berkembang yang sampai saat ini senantiasa masih berupaya memperbaiki keadaan, melalui pengembangan wilayah yang dikenal sebagai upaya pendekatan pembangunan dalam kegiatan perencanaan. Partisipasi masyarakat merupakan aspek yang penting dalam pembangunan suatu daerah. Selain itu, partisipasi masyarakat adalah salah satu faktor penentu serta sekaligus sebagai indikator keberhasilan pembangunan.

Menurut Suryono (2001) partisipasi merupakan ikut sertanya masyarakat dalam pembangunan, ikut dalam kegiatan pembangunan dan ikut memanfaatkan dan menikmati hasil-hasil pembangunan. Seberapa 
keras usaha pemerintah membangun, jika tidak melibatkan dan menumbuhkan partisipasi dari masyarakat serta tidak didukung oleh masyarakat, maka tingkat keberhasilan pembangunan dan keberlanjutan program pembangunan akan berbeda dengan kondisi jika masyarakat berpartisipasi. Oleh karena itu, dalam pelaksanaan pembangunan harus ada sebuah rangsangan dari pemerintah agar masyarakat dalam keikutsertaannya memiliki motivasi yang kuat untuk turut mensukseskan program pemerintah tersebut.

Undang-Undang Dasar 1945 mengamanatkan secara tegas bahwa, setiap warga negara Indonesia, mempunyai hak dan kewajiban serta kesempatan yang sama untuk memperoleh penghidupan yang layak. Dalam konteks pembahasan ini bisa diartikan bahwa, tidak ada perbedaan antara laki-laki dan perempuan untuk ikut serta dalam mensukseskan program pembangunan. Partisipasi masyarakat khususnya perempuan dapat difungsikan juga sebagai faktor penentu keberhasilan sebuah program pembangunan dari pemerintah. Partisipasi perempuan dalam pembangunan tidak hanya terbatas pada pelaksanaan fungsinya dalam keluarga, melainkan juga dalam kehidupan masyarakat luas. Dalam hal ini perempuan Indonesia mempunyai kesempatan yang sama dengan kaum laki-laki untuk ikut berpartisipasi dalam pembangunan.

Partisipasi yang dimaksud adalah keterlibatan perempuan dalam pembangunan pertanian khususnya infrastruktur jalan pertanian di Desa Watulaney Timu Kecamatan Lembean Timur Kabupaten Minahasa. Pembangunan infrastruktur jalan pertanian mempunyai peran yang sangat penting dalam pembangunan nasional serta termasuk pemenuhan kebutuhan masyarakat dengan tujuan untuk meningkatkan kesejahteraan masyarakat, dan yang menjadi jenis kegiatan di desa tersebut adalah pengerasan jalan menuju ke perkebunan.

Desa Watulaney Timu merupakan salah satu desa yang pada umumnya pekerjaan masyarakat sebagai petani baik kaum laki-laki maupun kaum perempuan. Dan Desa Watulaney Timu adalah desa yang telah mengalami pemekaran dari Desa Watulaney. Sehingga desa tersebut terbagi menjadi dua desa yaitu, Desa Watulaney Timu dan Desa Watulaney Amian, kemudian di pimpin oleh dua Kepala Desa (Hukum Tua). Dengan adanya pembangunan berupa infrastruktur jalan pertanian dapat memudahkan masyarakat di desa tersebut untuk mengangkut hasil perkebunan dan dibawa ke desa.

Berdasarkan penjelasan yang telah diuraikan, penulis meneliti tentang partisipasi perempuan dalam pembangunan pertanian dan yang menjadi lokasi penelitian adalah Desa Watulaney Timu. Hal ini disebabkan karena di desa tersebut yang sementara melaksanakan pembangunan berupa infrastruktur jalan pertanian. Sehingga penulis mengangkat judul tentang
Partisipasi Perempuan Dalam Pembangunan Infrastruktur Jalan Pertanian di Desa Watulaney Timu Kecamatan Lembean Timur Kabupaten Minahasa.

\section{Rumusan Masalah}

Permasalahan yang dimunculkan adalah bagaimana partisipasi perempuan dalam pembangunan infrastruktur jalan pertanian di Desa Watulaney Timu Kecamatan Lembean Timur Kabupaten Minahasa?

\section{Tujuan Penelitian}

Tujuan yang ingin dicapai dalam penelitian ini yaitu untuk mengetahui seberapa besar partisipasi perempuan dalam pembangunan infrastruktur jalan pertanian di Desa Watulaney Timu Kecamatan Lembean Timur Kabupaten Minahasa.

\section{Manfaat Penelitian}

Manfaat dari penelitian ini adalah sebagai sumber ilmu pengetahuan tentang partisipasi perempuan dalam pembangunan infrastruktur jalan pertanian. Diharapkan kepada pembaca untuk mendapat pengetahuan tentang partisipasi perempuan dalam pembangunan infrastruktur jalan pertanian dan dapat menjadi bahan studi referensi untuk penulis selanjutnya.

\section{METODE PENELITIAN}

\section{Lokasi dan Waktu Penelitian}

Penelitian ini dilakukan di Desa Watulaney Kecamatan Lembean Timur Kabupaten Minahasa. Penelitian ini berlangsung selama 3 bulan yaitu dari bulan Oktober sampai Desember 2018.

\section{Metode Pengambilan Sampel}

Metode pengambilan sampel menggunakan metode Purposive sampling, yaitu metode pengambilan sampel yang dilakukan secara sengaja. Dalam hal ini yang menjadi responden yaitu masyarakat khususnya perempuan, di ambil 10 perempuan yang terlibat dalam pembangunan infrastruktur jalan pertanian di Desa Watulaney Timu Kecamatan Lembean Timur Kabupaten Minahasa.

\section{Metode Pengumpulan Data}

Metode pengumpulan data adalah data primer dan data sekunder. Data primer adalah data yang di peroleh dari wawancara secara langsung dengan menggunakan kuesioner, sedangkan data sekunder adalah data yang diperoleh melalui pemerintah Desa Watulaney Timu serta dokumen instansi yang berkaitan dengan penelitian ini yaitu dokumen yang memuat informasi tentang profil Desa Watulaney Timu. 


\section{Konsep Pengukuran Variabel}

Variabel yang diukur dalam penelitian ini adalah sebagai berikut:

A. Karakteristik meliputi:

1. Nama

2. Umur

3. Tingkat pendidikan

4. Pekerjaan

B. Penilaian partisipasi terhadap pembangunan pertanian khususnya infrastruktur jalan pertanian yaitu, melihat keterlibatan perempuan dalam melakukan kegiatan pembangunan mulai dari tahap perencanaan, pelaksanaan, serta evaluasi yang di ukur oleh:

1. Tahap Perencanaan

a) Responden memberikan Partisipasi Pikiran berupa:

SA: Sangat aktif dalam memberikan pendapat dan saran

KA: Kurang aktif dalam memberikan pendapat dan saran

TA: Tidak aktif dalam memberikan pendapat dan saran

b) Responden memberikan Partisipasi Tenaga berupa: SA: Menghadiri pertemuan rapat lebih dari 5 kali

KA: Menghadiri pertemuan rapat 1-3 kali

TA: Tidak menghadiri rapat sama sekali

c) Responden memberikan Partisipasi Keterampilan berupa:

SA: Sangat aktif dalam memberikan ide kreatif dan motivasi

KA: Kurang aktif dalam memberikan ide kreatif dan motivasi

TA: Tidak memberikan ide kreatif dan motivasi sama sekali

d) Responden memberikan Partisipasi Harta dan Benda berupa:

SA: Sangat aktif dalam memberikan sumbangan, makanan/minuman serta meminjamkan barang/benda

KA:Hanya beberapa kali memberikan sumbangan, makanan/minuman, barang

TA: Tidak memberikan apapun sama sekali.

2. Tahap Pelaksanaan

a) Responden memberikan Partisipasi Pikiran berupa:

SA: Sangat aktif dalam memberikan usulan, pendapat dan saran

KA: Hanya beberapa kali memberikan usulan, pendapat dan saran

TA: Tidak sama sekali memberikan usulan, pendapat dan saran

b) Responden memberikan Partisipasi Tenaga berupa: SA: Mengikuti kerja bakti

KA: Hanya beberapa kali mengikuti kerja bakti

TA: Tidak mengikuti kerja bakti sama sekali

c) Responden memberikan Partisipasi Keterampilan berupa:

SA: Selalu menyalurkan keahlian/kemahiran dalam pelaksanaan pembangunan
KA: Hanya beberapa kali menyalurkan keahlian/kemahiran

TA: Tidak menyalurkan keahlian/kemahiran sama sekali

d) Responden memberikan Partisipasi Harta dan

Benda berupa:

SA: Selalu memberikan makanan/minuman dan meminjamkan peralatan kerja

KA: Kurang aktif memberikan makanan/ minuman dan meminjamkan peralatan kerja

TA: Tidak memberikan makanan/minuman serta tidak meminjamkan peralatan kerja sama sekali

3. Evaluasi

a) Responden memberikan Partisipasi Pikiran berupa:

SA: Selalu memberikan saran/masukan

KA: Hanya beberapa kali memberikan saran/masukan

TA: Tidak sama sekali memberikan saran/masukan

b) Responden memberikan Partisipasi Tenaga berupa:

SA: Selalu mengikuti kerja bakti

KA: Hanya beberapa kali mengikuti kerja bakti

TA: Tidak memberikan partisipasi tenaga sama sekali

c) Responden memberikan Partisipasi Keterampilan berupa:

SA: Selalu menyalurkan kemampuan dalam memberikan penilaian pada proses pembangunan

KA: Hanya beberapa kali menyalurkan kemampuan dalam memberikan penilaian

TA: Tidak menyalurkan kemampuan sama sekali

d) Responden memberikan Partisipasi Harta dan

Benda berupa:

SA: Selalu memberikan makanan/minuman dan meminjamkan peralatan kerja

KA: Beberapa kali memberikan makanan/minuman dan meminjamkan peralatan kerja

TA: Tidak memberikan makanan/minuman dan peralatan kerja sama sekali

Dimana SA (sangat aktif), KA (kurang aktif), dan TA (tidak aktif).

\section{Metode Analisis Data}

Metode analisis data yang digunakan dalam penelitian ini adalah metode analisis deskriptif kualitatif, dimana metode ini mendeskripsikan setiap data yang diambil dari partisipasi perempuan kemudian disajikan dalam bentuk tabel, dan untuk pengukuran partisipasi perempuan menggunakan skala likert.

Skala likert digunakan untuk mengukur sikap, pendapat, dan persepsi seseorang atau sekelompok orang tentang fenomena sosial (Sugiono 2009). Dengan cara perhitungan skor sebagai berikut:

Cara perhitungan skor keseluruhan untuk mengetahui Partisipasi Perempuan:

Jumlah skor seluruh kriteria = Capaian jumlah skor x jumlah responden $\times$ instrument petantyaan 


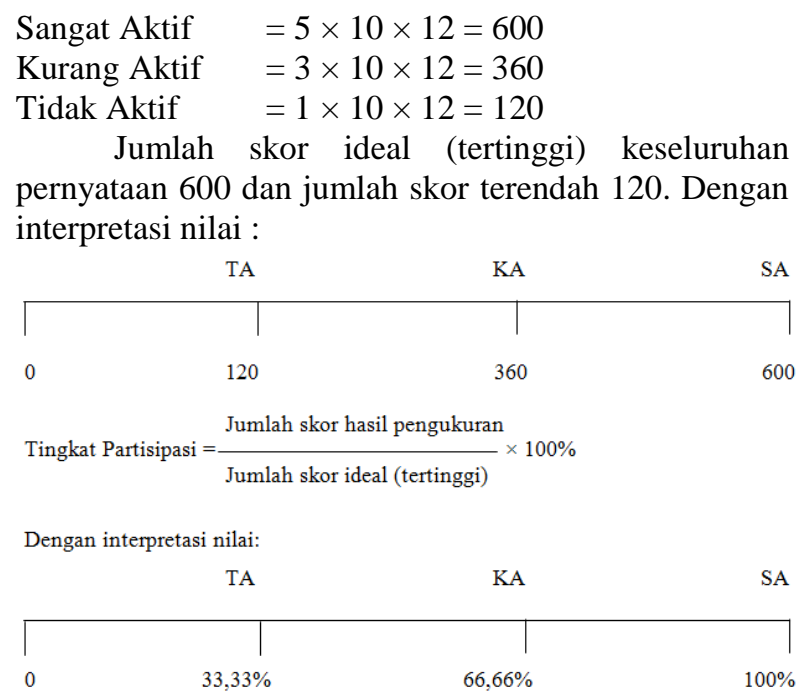

Keterangan kriteria interpretasi skor:

$\begin{array}{ll}\text { Angka 0\%-33\% } & =\text { Tidak Aktif } \\ \text { Angka 33\%-66\% } & =\text { Kurang Aktif } \\ \text { Angka 66\%-100\% } & =\text { Sangat Aktif }\end{array}$

\section{HASIL DAN PEMBAHASAN}

\section{Profil Desa Watulaney Timu}

Data profil Desa Watulaney Timu yang diambil dalam penelitian ini mencakup letak geografis, luas wilayah, dan batas administrasi, serta jumlah penduduk Desa Watulaney Timu.

\section{Letak Geografis, Luas Wilayah, dan Batas Administrasi}

Dalam penelitian ini, wilayah yang termasuk adalah wilayah administrasi Desa Watulaney Timu, merupakan salah satu desa yang terletak di Kecamatan Lembean Timur, yang merupakan bagian dari Kabupaten Minahasa. Desa Watulaney Timu memiliki jarak dengan ibu kota kecamatan 4 kilometer, jarak dengan ibu kota kabupaten 22 kilometer, dan jarak dengan ibu kota provinsi 64 kilometer. Desa Watulaney Timu memiliki luas wilayah sekitar 700 hektar dan luas pemukiman 20 hektar yang terdiri atas 5 jaga. Dengan batas wilayah sebagai berikut:

Sebelah Utara : Desa Watulaney Amian

Sebelah Timur : Desa Parentek, Laut Maluku

Sebelah Selatan : Desa Karor, Toulimembet

Sebelah Barat : Desa Eris, Desa Telap

Topografi Desa Watulaney Timu, berbukitbukit dan berada di ketinggian tanah dari permukiman air laut 0.650 meter dengan tingkat kemiringan tanah 0-4 derajat dan suhu rata-rata harian $28^{\circ} \mathrm{C}$.

\section{Jumlah Penduduk Desa Watulaney Timu}

Berdasarkan data penduduk Desa Watulaney Timu, sebanyak 907 jiwa dengan jumlah kepala keluarga (KK) 309 KK yang terdiri dari 5 jaga. Pada
Tabel 1 menunjukkan bahwa jumlah penduduk lakilaki lebih banyak dari jumlah penduduk perempuan. Jumlah penduduk laki-laki yang lebih banyak di jaga IV sebanyak 119 orang dan jumlah penduduk laki-laki yang paling sedikit di jaga $V$ dengan jumlah 62 orang sedangkan jumlah penduduk perempuan paling banyak berada di jaga III sebanyak 104 orang dan paling sedikit di jaga $V$ dengan jumlah 60 orang. Sehingga total jumlah penduduk paling besar berada pada jaga IV sebanyak 213 orang atau $23.5 \%$ sedangkan total jumlah penduduk paling sedikit berada pada jaga $\mathrm{V}$ dengan jumlah 122 orang atau 13.5\%. Persentase jumlah KK yang paling besar di jaga I sebesar $76 \mathrm{KK}$ atau $24.6 \%$ dan jumlah KK yang sedikit di jaga $\mathrm{V}$ dengan jumlah $41 \mathrm{KK}$ atau $13.3 \%$.

Tabel 1. Jumlah Penduduk Desa Watulaney Timu

\begin{tabular}{llllllll}
\hline \multirow{2}{*}{ No } & Jaga & \multicolumn{3}{c}{ Jumlah Penduduk } & \multirow{2}{*}{$(\%)$} & KK & \multirow{2}{*}{$(\%)$} \\
\cline { 3 - 5 } & & L & P & Total & & & \\
\hline 1. & I & 95 & 97 & 192 & 21.2 & 76 & 24.6 \\
2. & II & 97 & 87 & 184 & 20.3 & 56 & 18.1 \\
3. & III & 92 & 104 & 196 & 21.6 & 65 & 21.0 \\
4. & IV & 119 & 94 & 213 & 23.5 & 71 & 23.0 \\
5. & V & 62 & 60 & 122 & 13.5 & 41 & 13.3 \\
\hline & Jumlah & 465 & 442 & 907 & 100.0 & 309 & 100.0 \\
\hline
\end{tabular}

Sumber: Data Sekunder, Kantor Desa Watulaney 2018

\section{Karakteristik Responden}

Karakteristik Responden dalam penelitian ini meliputi umur responden, tingkat pendidikan, dan pekerjaan responden.

\section{Umur Responden}

Umur responden menjelaskan tentang usia setiap responden. Perbedaan usia atau umur juga dapat mempengaruhi tingkat partisipasi karena dalam pembangunan, produktivitas seseorang dapat di pengaruhi oleh umur. Misalnya umur yang lebih muda tingkat produktivitasnya tinggi sedangkan umur yang $>50$ tingkat produktivitasnya lebih rendah.

\begin{tabular}{|c|c|c|c|}
\hline No & Umur (Tahun) & $\begin{array}{c}\text { Jumlah } \\
\text { Responden (orang) }\end{array}$ & Persentase (\%) \\
\hline 1. & $30-39$ & 4 & 40 \\
\hline 2. & $40-49$ & 5 & 50 \\
\hline 3. & 50 & 1 & 20 \\
\hline & Jumlah & 10 & 100 \\
\hline
\end{tabular}

Tabel 2 menunjukkan bahwa hasil persentase terbesar adalah umur 40-49 tahun atau 50\% dengan jumlah 5 orang. Sedangkan, persentase terkecil adalah umur 50 tahun atau $10 \%$ dengan jumlah 1 orang. Jumlah umur responden tidak jauh berbeda, dimana umur 30-39 ada 4 orang, umur 40-49 5 orang dan umur 50 ada 1 orang. Pada tabel ini dapat dilihat bahwa responden terbanyak adalah umur $<50$.

\section{Tingkat Pendidikan}

Pendidikan merupakan faktor terpenting yang dapat mempengaruhi tingkat pengetahuan. Pendidikan dianggap penting karena, semakin tinggi pendidikan 
yang diperoleh semakin luas pengetahuan yang dimiliki. Pendidikan juga merupakan kebutuhan pokok atau sarana utama dalam peningkatan sumber daya manusia. Misalnya dalam pembangunan, apabila semakin tinggi tingkat pendidikan, tentunya semakin luas pengetahuan tentang pembangunan tersebut serta bentuk partisipasi yang baik dan benar dapat disalurkan untuk kepentingan dan kesejahteraan bersama. Pada uraian pendidikan responden di Desa Watulaney Timu dapat dilihat pada Tabel 3.

\begin{tabular}{|c|c|c|c|}
\hline No & $\begin{array}{c}\text { Tingkat } \\
\text { Pendidikan }\end{array}$ & $\begin{array}{c}\text { Jumlah } \\
\text { Responden (orang) }\end{array}$ & Persentase (\%) \\
\hline 1. & SD & 1 & 10 \\
\hline 2. & SM & 2 & 20 \\
\hline 3. & SMA/SMK & 7 & 70 \\
\hline & Jumlah & 10 & 100 \\
\hline
\end{tabular}

Tabel 3 menunjukkan bahwa tingkat pendidikan responden di Desa Watulaney Timu tergolong rendah. Dimana pada tingkat pendidikan tamatan SMA/SMK berjumlah 7 orang atau $70 \%$ sedangkan tingkat pendidikan Sekolah Menegah Pertama (SMP) 2 orang atau $20 \%$ dan Sekolah Dasar (SD) 1 orang atau $10 \%$. Hal ini disebabkan karena tingkat ekonomi keluarga yang tidak mencukupi untuk membiayai pendidikan dan adanya pengaruh adat istiadat yang beranggapan bahwa bertani adalah yang utama untuk memenuhi kebutuhan.

\section{Pekerjaan Responden}

Responden menurut pekerjaan menjelaskan tentang jenis-jenis pekerjaan, yang merupakan sumber pendapatan bagi responden itu sendiri. Responden Desa Watulaney Timu menurut pekerjaan dapat dilihat pada Tabel 4.

Tabel 4. Jumlah Responden menurut Pekerjaan

\begin{tabular}{llcc}
\hline No & \multicolumn{1}{c}{ Pekerjaan } & $\begin{array}{c}\text { Jumlah } \\
\text { Responden (orang) }\end{array}$ & Persentase (\%) \\
\hline 1. & IRT & 9 & 90 \\
2. & Pegawai Swasta & 1 & 10 \\
\hline & Jumlah & 10 & 100 \\
\hline
\end{tabular}

Sumber: Diolah dari Data Primer

Tabel 4 menjelaskan bahwa sebagian besar pekerjaan dari responden di Desa Watulaney Timu adalah Ibu Rumah Tangga (IRT) dengan jumlah 9 orang atau 90\% sedangkan pegawai swasta hanya berjumlah 1 orang atau $10 \%$.

\section{Partisipasi Perempuan dalam Pembangunan Infrastruktur Jalan Pertanian}

\section{Tahap Perencanaan}

Pada tahap perencanaan pembangunan, dibutuhkan keikutsertaan atau keterlibatan masyarakat dalam pembangunan, melalui beberapa tahapan yang termuat dalam program pembangunan itu sendiri. Sebagaimana program tersebut di mulai dari penggalian gagasan pada tingkat jaga dan kemudian ke tahap selanjutnya yaitu musyawarah desa (Musdes). Kegiatan ini bertujuan menggali setiap gagasan, pendapat, serta menyerap setiap aspirasi dari masyarakat untuk keberlanjutan program kegiatan pembangunan tersebut. Dan kemudian diikutsertakan dalam musyawarah rencana pembangunan (Musrembang) pada tingkat kecamatan. Pada program pembangunan ini yang terlibat dalam kegiatan tersebut bukan hanya kaum laki-laki saja tetapi dari kaum perempuan juga ikut terlibat. Dalam hal ini bentuk partisipasi perempuan yang diberikan pada tahap perencanaan yaitu pikiran, tenaga, keterampilan, harta dan benda. Untuk melihat seberapa besar partisipasi perempuan tersebut dapat dilihat pada Tabel 5.

\begin{tabular}{|c|c|c|c|c|c|}
\hline No & Kriteria & Skor & $\begin{array}{c}\text { Jumlah } \\
\text { Responden (orang) }\end{array}$ & Total Skor & Persentase (\%) \\
\hline 1. & SA & 5 & 5 & 25 & 73.53 \\
\hline 2. & KA & 3 & 2 & 6 & 17.65 \\
\hline 3. & TA & 1 & 3 & 3 & 8.82 \\
\hline \multicolumn{3}{|c|}{ Jumlah } & 10 & 34 & 100 \\
\hline
\end{tabular}

Tabel 5 menunjukkan bahwa jumlah responden yang tidak aktif ada 3 orang atau sekitar $8.82 \%$ adalah responden yang sama sekali tidak berpartisipasi pikiran berupa memberikan pendapat dan saran pada pertemuan rapat untuk perencanaan pembangunan, sedangkan responden yang sangat aktif berjumlah 5 orang atau sekitar $73.53 \%$ responden yang selalu memberikan pendapat serta saran, dan responden yang kurang aktif sisanya 2 orang atau sekitar $17.65 \%$ hanya sekali berpartisipasi pikiran berupa memberikan pendapat dan saran pada pertemuan rapat dalam tahap perencanaan. Berdasarkan hasil persentase menunjukkan bahwa partisipasi perempuan berupa pikiran seperti pendapat dan saran dapat dikatakan tergolong sangat aktif. Hal ini disebabkan karena perempuan yang terlibat pada pembangunan tersebut sangat antusias dalam perencanaan pembangunan yang akan dilaksanakan.

\begin{tabular}{|c|c|c|c|c|c|}
\hline No & Kriteria & Skor & $\begin{array}{c}\text { Jumlah } \\
\text { Responden (orang) }\end{array}$ & Total Skor & Persentase (\%) \\
\hline 1. & SA & 5 & 9 & 45 & 93.75 \\
\hline 2. & KA & 3 & 1 & 3 & 6.25 \\
\hline 3. & TA & 1 & & & \\
\hline \multicolumn{3}{|c|}{ Jumlah } & 10 & 48 & 100 \\
\hline
\end{tabular}

Tabel 6 menunjukkan jumlah responden 9 orang atau $93.75 \%$ adalah responden yang sangat aktif memberikan partisipasi tenaga berupa menghadiri pertemuan rapat lebih dari 5 kali dan 
jumlah responden 1 orang atau $6.25 \%$ hanya menghadiri pertemuan rapat 1 kali saja atau kurang aktif sedangkan responden yang tidak aktif, tidak ada. Berdasarkan hasil persentase tersebut dapat dikatakan bahwa partisipasi perempuan dalam menyumbangkan tenaga berupa kehadiran dalam pertemuan rapat pada tahap perencanaan tergolong sangat aktif. Hal ini disebabkan karena perempuan yang ikut terlibat sangat mendukung adanya program pembangunan yang sedang direncanakan untuk kesejahteraan masyarakat bersama.

\begin{tabular}{|c|c|c|c|c|c|}
\hline No & Kriteria & Skor & $\begin{array}{c}\text { Jumlah } \\
\text { Responden (orang) } \\
\end{array}$ & Total Skor & Persentase (\%) \\
\hline 1. & SA & 5 & 3 & 15 & 62.5 \\
\hline 2. & KA & 3 & 1 & 3 & 12.5 \\
\hline 3. & TA & 1 & 6 & 6 & 25 \\
\hline & Jumlah & & 10 & 24 & 100 \\
\hline
\end{tabular}

Tabel 7 menunjukkan 6 orang atau 25\% sama sekali tidak memberikan ide kreatif dan motivasi pada tahap perencanaan pembangunan sedangkan 3 orang atau $62.5 \%$ memberikan ide kreatif berupa usulan membuat sapu dari pohon seho untuk melengkapi peralatan kerja yang akan digunakan nanti untuk pembersihan lokasi dan memberikan motivasi berupa dorongan atau memberikan semangat untuk bertindak dalam melakukan pekerjaan yang telah di sepakati bersama dan 1 orang sisanya dengan jumlah persentase $12.5 \%$ hanya memberikan semangat saja . Berdasarkan Tabel 7 dapat dikatakan bahwa partisipasi perempuan dalam memberikan keterampilan berupa menyalurkan ide kreatif dan motivasi, tergolong kurang aktif. Hal ini disebabkan karena perempuan yang terlibat dalam pembangunan di tahap perencanaan kurang memiliki wawasan yang lebih luas pada pembangunan jalan pertanian.

Tabel 8. Partisipasi Harta Benda Berupa Memberikan Sumbangan, Makanan/Minuman dan Meminjamkan barang

\begin{tabular}{|c|c|c|c|c|c|}
\hline No & Kriteria & Skor & $\begin{array}{c}\text { Jumlah } \\
\text { Responden (orang) }\end{array}$ & Total Skor & Persentase (\%) \\
\hline 1. & SA & 5 & 5 & 15 & 65.79 \\
\hline 2. & KA & 3 & 4 & 12 & 31.58 \\
\hline 3. & TA & 1 & 1 & 1 & 2.63 \\
\hline & Jumlah & & 10 & 38 & 100 \\
\hline
\end{tabular}

Sumber: Diolah dari Data Primer

Tabel 8 menunjukkan jumlah responden yang sangat aktif memberikan sumbangan berupa uang untuk membeli kue, teh/kopi, air mineral dan meminjamkan laptop serta membawa makanan berupa lauk/pauk, buah-buahan, dan meminjamkan peralatan makan/minum pada tahap perencanaan berjumlah 5 orang atau $65.79 \%$ dan 4 orang atau $31.58 \%$ responden yang kurang aktif memberikan partisipasi harta benda, 1 orang lainnya atau $2.63 \%$ responden yang tidak memberikan partisipasi sama sekali. Berdasarkan hasil persentase yang diperoleh, dapat dikatakan bahwa partisipasi perempuan berupa harta dan benda dalam memberikan sumbangan serta makanan/minuman tergolong sangat aktif. Hal ini disebabkan karena mayarakat khususnya perempuan yang terlibat pada pembangunan tersebut, sangat aktif dalam memberikan sumbangan, makanan/ minuman, bahkan meminjamkan barang.

\section{Tahap Pelaksanaan}

Tahap pelaksanaan pembangunan ini adalah tahap dimana melibatkan fisik dari para masyarakat lebih khusus perempuan yang terlibat langsung dalam pelaksanaan kegiatan pembangunan jalan pertanian. Proses pembangunan ini dibutuhkan kerja sama serta partisipasi yang diwujudkan dalam bentuk tenaga, keterampilan, ide, harta dan benda berupa peralatan kerja, makanan minuman, demi mewujudkan kesejahteraan bersama dalam pembuatan jalan pertanian tersebut. Bentuk partisipasi perempuan yang diberikan pada tahap pelaksanaan, dapat dilihat pada Tabel 9.

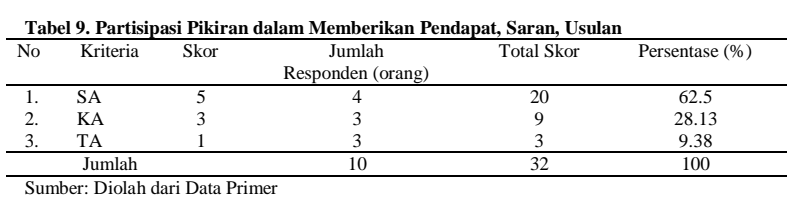

Tabel 9 menunjukkan bahwa 4 orang atau $62.5 \%$ adalah jumlah responden yang sangat aktif atau selalu memberikan pendapat, saran serta usulan tentang pembangunan jalan pertanian, sedangkan 3 orang atau sekitar $28.13 \%$ adalah responden yang sama sekali tidak pernah memberikan pendapat, saran, serta usulan pada tahap pelaksanaan pembangunan. Dan 3 orang sisanya atau 9.38\% adalah responden yang hanya sekali atau tidak sering memberikan pendapat, saran, serta usulan mengenai pembangunan jalan pertanian pada tahap pelaksanaan . Dalam hal ini, partisipasi perempuan berupa pikiran dalam memberikan pendapat, saran serta usulan dapat dikatakan kurang aktif. Disebabkan karena, pada tahap ini kurang banyak responden yang memahami tentang bagaimana proses pelaksanaan pembangunan jalan pertanian tersebut dan responden lebih tertarik langsung terlibat dalam menyumbangkan tenaga mereka dalam hal membantu pekerjaan untuk keberlanjutan proses pembangunan.

\begin{tabular}{llcccc}
\multicolumn{6}{c}{ Tabel 10. Partisipasi Tenaga dalam Mengikuti Kerja Bakti } \\
\hline No & Kriteria & Skor & $\begin{array}{c}\text { Jumlah } \\
\text { Responden (orang) }\end{array}$ & Total Skor & Persentase (\%) \\
\hline 1. & SA & 5 & 8 & 40 & 95.24 \\
2. & KA & 3 & 2 & & 4.76 \\
3. & TA & 1 & 10 & 42 & 100 \\
\hline \multicolumn{5}{l}{ Jumlah } \\
\hline \multicolumn{5}{l}{ Sumber: Diolah dari Data Primer }
\end{tabular}


Tabel 10 menunjukkan responden yang sama sekali tidak aktif memberikan partisipasi tenaga dalam bentuk mengikuti kerja bakti ada 2 orang atau $4.76 \%$ dan responden yang selalu memberikan partisipasi tenaga atau sangat aktif mengikuti kerja bakti berupa melakukan pembersihan lokasi berjumlah 8 orang dengan hasil persentase $95.24 \%$ sedangkan yang kurang akif tidak ada. Dengan hasil persentase yang diperoleh dapat dikatakan bahwa partisipasi perempuan dalam menyumbangkan tenaga tergolong sangat aktif. Hal ini disebabkan karena perempuan yang terlibat pada tahap pelaksanaan tersebut sangat antusias dalam memberikan partisipasi tenaga berupa mengikuti kerja bakti atau turut mengambil bagian pada proses pembangunan yang sementara berjalan.

\begin{tabular}{|c|c|c|c|c|c|}
\hline \multicolumn{2}{|c|}{ Tabel } & \multicolumn{2}{|c|}{$\begin{array}{l}\text { Partisipasi Keterampilan } \\
\text { Keahlian/Kemahiran }\end{array}$} & \multirow{2}{*}{$\begin{array}{c}\text { Berupa } \\
\text { Total Skor }\end{array}$} & \multirow{2}{*}{$\begin{array}{c}\text { Menyalurkan } \\
\text { Persentase (\%) }\end{array}$} \\
\hline No & Kriteria & Skor & $\begin{array}{c}\text { Jumlah } \\
\text { Responden (orang) }\end{array}$ & & \\
\hline 1. & SA & 5 & 4 & 20 & 71.43 \\
\hline 2. & KA & 3 & 1 & 3 & 10.71 \\
\hline 3. & TA & 1 & 5 & 3 & 17.86 \\
\hline & Jumlah & & 10 & 28 & 100 \\
\hline
\end{tabular}

Tabel 11 menunjukkan responden yang sangat aktif atau selalu menyalurkan keahlian/kemahiran yang di miliki seperti mencampur bahan material pembuatan beton dan menyambungkan kawat bronjong untuk pembangunan jalan pertanian, ada 4 orang atau $71.43 \%$ dan responden yang hanya sekali menyalurkan keahlian/kemahiran atau kurang aktif ada 1 orang dengan hasil persentase $10.71 \%$ serta responden yang sama sekali tidak memberikan partisipasi keterampilan dalam menyalurkan keahlian/kemahiran yang dimiliki ada 5 orang atau sekitar $17.86 \%$. Dalam hal ini partisipasi perempuan dalam memberikan keterampilan berupa menyalurkan keahlian atau kemahiran pada tahap pelaksanaan pembangunan, tegolong kurang aktif. Karena perempuan yang terlibat pada proses pembangunan tersebut kurang memiliki keahlian dalam bidang tukang bangunan.

Tabel 12. Partisipasi Harta dan Benda Berupa Menyumbangkan Makanan/Minuman, Uang serta Meminjamkan Peralatan Kerja

\begin{tabular}{|c|c|c|c|c|c|}
\hline No & Kriteria & Skor & $\begin{array}{c}\text { Jumlah } \\
\text { Responden (orang) }\end{array}$ & Total Skor & Persentase (\%) \\
\hline 1. & SA & 5 & 8 & 40 & 86.96 \\
\hline 2. & KA & 3 & 2 & 6 & 13.04 \\
\hline 3. & TA & 1 & & & \\
\hline \multicolumn{3}{|c|}{ Jumlah } & 10 & 46 & 100 \\
\hline
\end{tabular}

Tabel 12 menunjukkan bahwa jumlah responden yang tidak aktif sama sekali tidak ada sedangkan yang sangat aktif ada 8 orang atau $86.96 \%$ responden ini yang selalu memberikan partisipasi harta dan benda berupa menyumbangkan uang untuk membeli kue dan air mineral (aqua), menyumbangkan makanan seperti lauk pauk untuk makan siang dan minuman seperti teh/kopi, meminjamkan peralatan kerja seperti cangkul, partikula, tropol, ember, gerobak. Dan 2 orang sisanya atau $13.04 \%$ responden yang hanya sekali memberikan partisipasi harta dan benda. Berdasarkan hasil persentase tersebut dapat dikatakan bahwa pada tahap pelaksanaan partisipasi perempuan berupa menyumbangkan peralatan kerja, makanan/minuman serta uang tergolong sangat aktif. Karena perempuan yang terlibat dalam tahap pelaksanaan ini sangat aktif dalam hal menyumbangkan makanan/minuman dan uang serta meminjamkan peralatan kerja yang dibutuhkan pada proses pembangunan yang sementara dilaksanakan.

\section{Evaluasi}

Dalam tahap evaluasi ini dimana masyarakat khususnya perempuan yang terlibat pada kegiatan pembangunan diharapkan agar dapat turut mengambil bagian untuk proses pemantauan atau penilaian serta terlibat secara fisik dan materi dalam bentuk pikiran, tenaga, keterampilan serta harta dan benda untuk keberlangsungan proses pembangunan yang sementara berlangsung. Bentuk partisipasi perempuan tersebut dalam tahap evaluasi dapat dilihat pada Tabel 13.

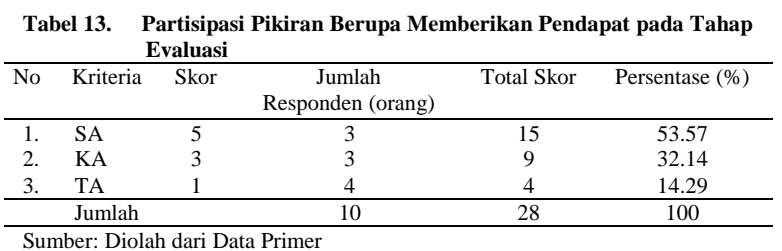

Tabel 13 menunjukkan jumlah responden yang sangat aktif memberikan partisipasi pikiran berupa pendapat misalnya penilaian terhadap pembangunan jalan pertanian yang sementara berlangsung, pada saat rapat evaluasi ada 3 orang atau $53.57 \%$ serta jumlah responden yang tidak aktif memberikan partisipasi pikiran berupa pendapat ada 4 orang atau $14.29 \%$ dan jumlah responden yang kurang aktif ada 3 orang atau $32.14 \%$. Responden pada tahap evaluasi dalam memberikan partisipasi pikiran berupa pendapat dalam bentuk penilaian dari hasil proses pembangunan yang masih sementara berlangsung dapat dikatakan tergolong kurang aktif. Hal ini disebabkan karena beberapa responden cenderung masih lebih fokus untuk melihat perkembangan selanjutnya dalam proses pembangunan yang sementara berjalan sehingga responden yang tidak aktif belum memberikan pendapat berupa penilaian terhadap pembangunan dan beberapa responden yang kurang aktif hanya memantau perkembangan tapi tidak memberikan pendapat berupa penilaian pada proses pembangunan tersebut 


Tabel 14. Partisipasi Tenaga dalam Bentuk Mengikuti Kerja Bakti
\begin{tabular}{cccccc}
\hline No & Kriteria & Skor & $\begin{array}{c}\text { Jumlah } \\
\text { Responden (orang) }\end{array}$ & Total Skor & Persentase (\%) \\
\hline 1. & SA & 5 & 7 & 35 & 87.5 \\
2. & KA & 3 & 1 & 3 & 7.5 \\
3. & TA & 1 & 2 & 2 & 5 \\
\hline \multicolumn{7}{l}{ Jumlah } \\
Sumber: Diolah dari Data Primer & 10 & 40 & 100 \\
\hline
\end{tabular}

Tabel 14 menunjukkan jumlah responden yang tidak aktif atau sama sekali tidak memberikan partisipasi tenaga berupa mengikuti kerja bakti ada 2 orang dengan jumlah persentase 5\% dan responden yang kurang aktif atau hanya sekali datang mengikuti kerja bakti pada tahap evaluasi berjumlah 1 orang atau $7.5 \%$ sedangkan jumlah responden yang selalu mengikuti kerja bakti atau sangat aktif ada 7 orang dengan hasil persentase $87.5 \%$. Dalam tahap ini responden dapat dikatakan tergolong sangat aktif karena, perempuan yang terlibat langsung dalam memberikan partisipasi tenaga berupa mengikuti kegiatan kerja bakti sangat antusias dalam menjalankan proses pembangunan yang sementara berlangsung.

Tabel 15. Partisipasi Keterampilan Berupa Menyalurkan Keahlian/Kemahiran

\begin{tabular}{|c|c|c|c|c|c|}
\hline No & Kriteria & Skor & $\begin{array}{c}\text { Jumlah } \\
\text { Responden (orang) }\end{array}$ & Total Skor & Persentase (\%) \\
\hline 1. & SA & 5 & 2 & 10 & 45.45 \\
\hline 2. & KA & 3 & 2 & 6 & 27.27 \\
\hline 3. & TA & 1 & 6 & 6 & 27.27 \\
\hline \multicolumn{3}{|c|}{ Jumlah } & 10 & 22 & 100 \\
\hline
\end{tabular}

Tabel 15 menunjukkan bahwa jumlah responden yang sangat aktif menyalurkan keahlian/kemahiran seperti mengangkat campuran menggunakan ember, dan mengangkut pasir menggunakan gerobak, berjumlah 2 orang atau $45.45 \%$ sedangkan responden yang kurang aktif atau hanya sekali menyalurkan keahlian/kemahiran seperti memprediksi bahan campuran material beton berjumlah 2 orang juga atau $27.27 \%$ dan jumlah responden yang sama sekali tidak menyalurkan keahlian/kemahiran pada partisipasi keterampilan ada 6 orang yang tidak aktif atau 27.27\%. Adanya evaluasi dalam memberikan partisipasi keterampilan karena, untuk melihat kemampuan atau keahlian yang dimiliki perempuan dalam proses pembangunan, sehingga perempuan yang memiliki keterampilan dapat dilibatkan untuk rencana pembangunan selanjutnya di Desa Watulaney Timu. Berdasarkan Tabel 15 dapat dikatakan bahwa partisipasi keterampilan dalam menyalurkan keahlian/kemahiran tergolong kurang aktif. Hal ini disebabkan karena perempuan yang terlibat pada tahap evaluasi dalam memberikan partisipasi keterampilan kurang memiliki kemahiran/keahlian yang dapat disalurkan dalam pembangunan jalan pertanian.

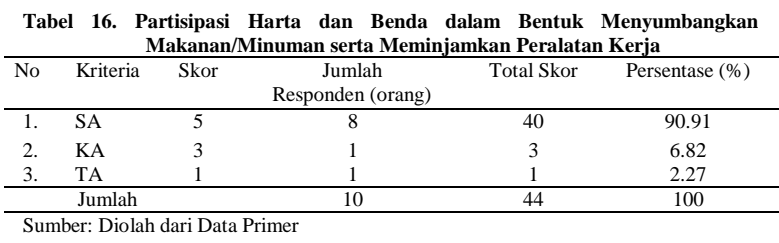

Tabel 16 jumlah responden yang tidak aktif atau sama sekali tidak memberikan partisipasi harta dan benda adalah 1 orang atau $2.27 \%$ dan yang kurang aktif atau hanya sekali memberikan partisipasi harta dan benda ada 1 orang juga atau $6.82 \%$ dan lainnya adalah jumlah responden yang sangat aktif memberikan partisipasi harta dan benda dalam bentuk menyumbangkan makanan minuman seperti kue, buahbuahan, nasi, lauk, kopi/teh, air mineral, dan meminjamkan peralatan kerja berupa ember, selang air, karung, gerobak, partikula, pada saat rapat evaluasi dan kerja bakti untuk kelanjutan proses pembangunan, ada 8 orang atau $90.91 \%$. Dalam tahap evaluasi ini responden memberikan partisipasi harta dan benda dalam bentuk menyumbangkan makanan/minuman serta peralatan kerja tergolong sangat aktif. Hal ini disebabkan karena kehidupan masyarakat di Desa Watulaney Timu kebersamaannya masih sangat kuat terutama dalam hal berbagi atau memberi sehingga sangat berpengaruh dalam kegiatan pembangunan yang ada di desa. Atau dapat dikatakan kehidupan bergotong royong di Desa Watulaney Timu masih tergolong tinggi.

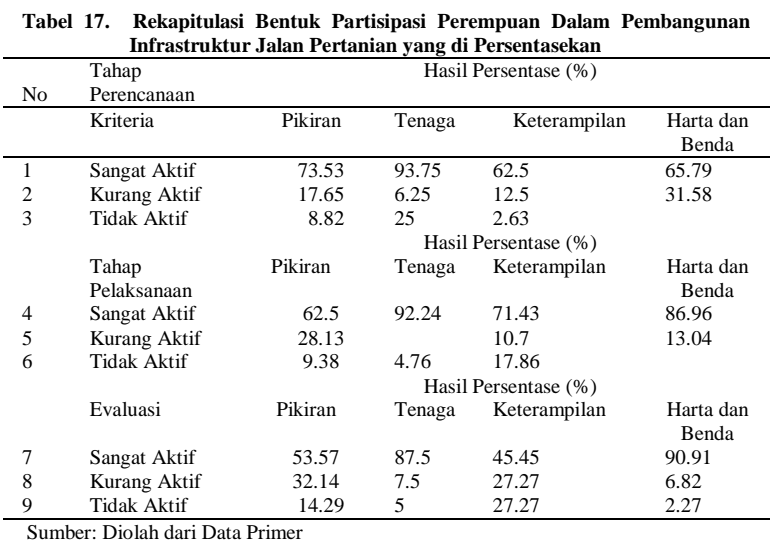

Tabel 17 menunjukkan pada tahap perencanaan responden kurang aktif dalam memberikan partisipasi keterampilan berupa ide kreatif untuk pembangunan jalan pertanian. Hal ini disebabkan karena perempuan yang terlibat dalam pembangunan kurang memiliki wawasan yang lebih luas tentang pembangunan jalan pertanian tersebut. Sedangkan pada tahap pelaksanaan responden sangat aktif memberikan partisipasi tenaga berupa mengikuti kerja bakti. Hal ini disebabkan karena perempuan yang terlibat pada tahap pelaksanaan sangat antusias dalam 
mengikuti kerja bakti atau turut mengambil bagian pada proses pembangunan. Selain itu, pada tahap pelaksanaan ini responden sangat aktif memberikan partisipasi harta dan benda berupa uang, makanan/minuman serta meminjamkan peralatan kerja yang dibutuhkan dan pada tahap evaluasi responden sangat aktif juga dalam memberikan partisipasi harta dan benda dalam bentuk menyumbangkan makanan/minuman serta meminjamkan peralatan kerja. Hal ini disebabkan karena, kehidupan masyarakat di Desa Watulaney Timu kebersamaannya masih sangat kuat terutama dalam hal berbagi atau memberi, sehingga sangat berpengaruh dalam kegiatan pembangunan di desa.

Gambar 1. Skala Skor Gabungan Partisipasi Perempuan pada Tahap Perencanaan

Interpretasi berdasarkan nilai skor $=144$

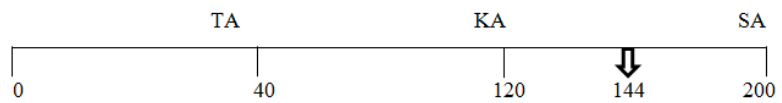

Interpretasi berdasarkan persentase $=\frac{144}{200} \times 100 \%=72$

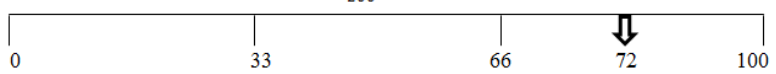

Berdasarkan skala likert tingkat partisipasi perempuan pada tahap perencanaan tergolong sangat aktif dalam memberikan partisipasi dengan hasil persentase $72 \%$.

Gambar 2. Skala Skor Gabungan Partisipasi Perempuan pada Tahap Pelaksanaan

Interpretasi berdasarkan nilai skor $=148$

\begin{tabular}{|l|l|lll|}
\multicolumn{1}{c}{} & \multicolumn{2}{c}{ KA } & & SA \\
\hline 0 & & 120 & $\sqrt{4}$ & \\
40 & & 148 & 200
\end{tabular}

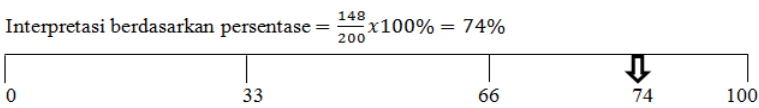

Berdasarkan skala likert tingkat partisipasi perempuan pada tahap pelaksanaan tergolong sangat aktif dalam memberikan partisipasi dengan hasil persentase $74 \%$.

Gambar 3. Skala Skor Gabungan Partisipasi Perempuan pada Tahap Evaluasi

Interpretasi berdasarkan nilai skor $=134$

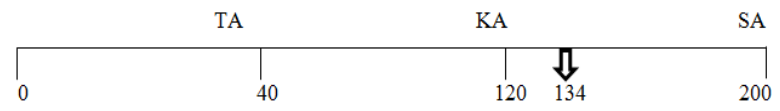

Interpretasi berdasarkan persentase $=\frac{134}{200} \times 100 \%=67$

\begin{tabular}{|c|c|c|c|}
\hline & & $\sqrt{ }$ & \\
\hline 0 & 33 & $\begin{array}{ll}66 & 67\end{array}$ & 100 \\
\hline
\end{tabular}

Berdasarkan skala likert, tingkat partisipasi perempuan pada tahap evaluasi tergolong sangat aktif dalam memberikan partisipasi dengan hasil persentase $67 \%$.

Gambar 4. Skala Skor Partisipasi Perempuan dalam Pembangunan Jalan Pertanian di Desa Watulaney Timu Interpretasi berdasarkan nilai skor $=426$

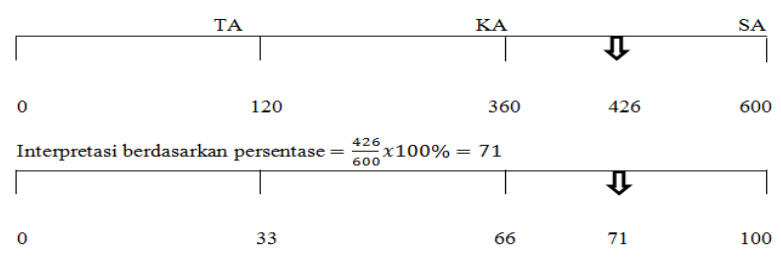

Berdasarkan skala likert tersebut maka tingkat partisipasi perempuan dalam pembangunan jalan pertanian di Desa Watulaney dapat dikatakan sangat aktif dalam memberikan partisipasi berupa pikiran, tenaga, keterampilan, serta harta dan benda dengan hasil persentase $71 \%$.

Tabel 18. Rekapitulasi Nilai Skor Partisipasi Perempuan dalam Pembangunan Infrastruktur Jalan Pertanian

\begin{tabular}{clcc}
\multicolumn{4}{c}{ Pembangunan Infrastruktur Jalan Pertanian } \\
\hline No & Tahap Partisipasi & Nilai & Persentase (\%) \\
1 & Perencanaan & 144 & 72 \\
2 & Pelaksanaan & 148 & 74 \\
3 & Evaluasi & 134 & 67 \\
\hline & Jumlah & 426 & 71
\end{tabular}

Sumber: Diolah dari Data Primer

Tabel 18 menunjukkan bahwa berdasarkan hasil perhitungan menggunakan skala likert, tingkat partisipasi perempuan dalam program pembangunan infrastruktur jalan pertanian di Desa Watulaney Timu masuk dalam kriteria sangat aktif memberikan partisipasi mulai dari tahap perencanaan, pelaksanaan dan evaluasi. Tingkat partisipasi yang paling tinggi ada padatahap pelaksanaan dengan jumlah total skor 144 atau 74\%. Hal ini disebabkan karena dalam tahap pelaksanaan partisipasi yang paling banyak diberikan adalah partisipasi pikiran berupa pendapat, saran serta usulan yang menyangkut program pembangunan jalan pertanian yang dilaksanakan. Selain itu, partisipasi harta dan benda berupa menyumbangkan makanan/minuman, uang dan peralatan kerja juga yang menyebabkan tingkat partisipasi di tahap pelaksanaan tergolong tinggi dan tingkat partisipasi yang paling rendah ada pada tahap evaluasi dengan jumlah total skor 134 atau 67\%. Dimana dalam tahap ini responden kurang aktif memberikan partisipasi pikiran berupa pendapat dalam bentuk ipenilaian terhadap pembangunan dan responden juga kurang aktif memberikan partisipasi keterampilan dengan alasan tidak memiliki keahlian khusus dalam pembangunan jalan pertanian. 


\section{KESIMPULAN DAN SARAN}

\section{Kesimpulan}

Partisipasi perempuan dalam program pembangunan infrastruktur jalan pertanian yang ada di Desa Watulaney Timu Kecamatan lembean Timur tergolong sangat aktif dalam memberikan partisipasi berupa pikiran, tenaga, keterampilan serta harta dan benda pada tahap perencanaan, tahap pelaksanaan dan evaluasi. Sedangkan tingkat partisipasi yang paling tinggi ada pada tahap pelaksanaan dan tingkat partisipasi yang paling rendah ada pada tahap evaluasi.

\section{Saran}

Partisipasi perempuan dalam pembangunan infrastruktur jalan pertanian yang tergolong sangat aktif ini, disebabkan karena adanya dukungan dari perempuan yang terlibat dalam program pembangunan tersebut. Oleh sebab itu, hal ini harus tetap dipertahankan oleh pemerintah desa setempat agar hubungan kerjasama yang baik tetap terjalin, sehingga setiap pembangunan yang akan diprogramkan di desa dapat terus diberikan kesempatan kepada perempuan atau selalu dilibatkan dalam setiap pembangunan selanjutnya yang direncanakan.

\section{DAFTAR PUSTAKA}

Siagian Sondang 2008. Administrasi Pembangunan: Konsep, Dimensi, dan Strateginya. Bumi Aksara. Jakarta.

Sugiono. 2009. Metode Penelitian Bisnis. CV Alfabeta. Bandung.

Suryono, Agus. 2001. Teori dan Isi Pembangunan. Universitas Negeri Malang, UM Press. Malang. 